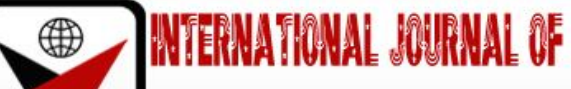

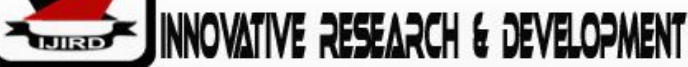

ISSN 2278 - 0211 (Online)

\section{Determinants of Ethical Procurement Practices in Public Entities in Tanzania: A Case Study of the National Audit Office (NA0) Headquarters, Dar Es Salaam}

\begin{tabular}{c} 
Aikande N. Lema \\
Student, Department of Procurement and Logistics Management, School of Business, \\
Mzumbe University, Tanzania. \\
Noel P. Mrope \\
Senior Lecturer, Department of Procurement and Logistics Management, School of Business, \\
Mzumbe University, Tanzania \\
\hline
\end{tabular}

\begin{abstract}
:
The study sought to determine factors influencing ethical procurement practices in public entities in Tanzania with specific reference to the National Audit Office Headquarters in Dar es Salaam. Specifically the study determined the effect of fairness on procurement ethical practices; investigated the effect of transparency on procurement ethical practices; assessed the effect of integrity on procurement ethical practices; and finally evaluated the effect of code of ethics and conduct on procurement ethical practices. A case study design adopted in which 23 (twenty three) employees were selected and served with questionnaires whereas 7 ( seven) employees were purposively sampled for a face to face interview, thus making a total of 30 (thirty) respondents. Quantitative data were analyzed through descriptive analysis, whereas qualitative data were analyzed through thematic and content analysis. The study findings indicate that adherence to code of ethics and conduct, fairness, transparency and integrity in the procurement process; have positive influence on the level of ethical practices achieved by the entity in its procurement process. The study concludes that enhanced ethical practices coupled with compliance with rules and regulations will close rooms for procurement corruption and fraud in the public entities.The study further recommends that ethical procurement practices should consistently be monitored and evaluated so as to ensure that procurement activities are conducted in a fair, transparent and in compliant manner with the applicable legal and regulatory framework.
\end{abstract}

Keywords: Procurement process, ethical practices, fairness, transparency, integrity

\section{Introduction}

Public procurement is a key economic activity of governments that represents a significant percentage of the Gross Domestic Product (GDP) generating huge financial flows, estimated on average at 10-15\% of GDP across the world (Zhou, 2012). Thus, an effective procurement system plays a strategic role in governments for avoiding mismanagement and waste of public funds.

Organization globally views that establishment of a regulatory body and comprehensive, transparent legal and institutional framework in procurement activities as one among the most important activities guarantees transparency and accountability in the use of public funds (Prier and McCue, 2006). Empirical literature over years have already shown that implementation of procurement ethical practices lead to higher organization performance both in developed and developing countries; which could then trickle down in terms of better organization success through minimizing corruption and other unethical practices in procurement process (John et al., 2010; \& Banihashemi, 2011). To achieve that Odhiambo, (2012) argued that public procurement has important economic and political implications, and ensuring that the process is economical and efficient is crucial. This requires in part that the whole procurement process should be well understood by the actors; government, the procuring entities and the business community or suppliers and other stakeholders, including professional associations, academic entities and the general public.

Some proponents give more emphasis to the importance procurement ethical practices and apprenticeships towards achieving the obligation of providing goods, works and services to meet a variety of citizen needs in developing. Achuora et al., (2011) concurred that public procurement regulation is one of the most important factors in carrying out effective public procurement audit. Consequently, there has been a debate among researchers in both developing and 
developed countries about procurement ethical practices in public sector organization. Kizito and Khomba, (2013)emphasizes on the importance of procurement ethics in procurement as essential for the creation of long-term relationships and the establishment of supplier goodwill. Their argument is that it is impossible to claim professional status for procurement without reference to a consideration of its ethical aspects. This is also supported by Jackson and Eunice(2014) who observe that an ethical based and effective procurement process can be built on the regulatory, corporate and functional legal framework for the benefit of all stakeholders in procurement activities. Thus, making public procurement an organized profession by building a body of public procurement knowledge is very critical.

Against this, there have been rising concerns about procurement ethical practices match procurement process. Since public procurement is fundamental to government service delivery as it often involves large sums of money; where problems are rampant, public procurement is one of the most serious and common areas for unethical procurement practices (Chigudu, 2014). Thus, emphasizing the implementation of ethical practice in public procurement is inevitable to ensure government service delivery.

\subsection{Problem Statement}

Ethical practice in public procurement ensure proper use of public resources towards better service delivery to the public (Ayoyi and Mukoswa, 2015). A good ethical procurement system that features transparency, accountability, and stakeholder participation can be a practical tool for carrying out effective, governance reforms (Quinot \& Arrowsmith 2013). Ethical practice in procurement ensure value for money, integrity in public spending practices, accountability to the public, and efficiency as the primary drivers for procurement practice in public organizations.(Manyaka and Sebola, 2013)

Despite the important ethical practices in public procurement, a culture of non-compliance combined with a lack of accountability and transparency contributed to the wholesale of looting and unethical procurement practices. Unethical conduct of procurement officials goes along with corruption, bribery, fraud and nepotism which impacts negatively on poor quality service delivered to the people(Zitha and Mathebula, 2015). Thus, unethical procurement practices will therefore relate to uncompetitive bidding, inadequate contract management, and the awarding of bids to employees and their family members, non-disclosure by suppliers, no supporting documents for procurement awards, using incorrect preferential point systems and thresholds, and acceptance of less than three quotations (Durant and Durant, 2013).

Minga, (2008) asserts that despite the availability of various pieces of legislations on procurement activities many public entities in Tanzania do not give proper attention in implementing ethical issues as it deserves in procurement process. Ngugi \& Mugo, (2012) observe that the potential for manipulation of contract awards and lack of fair competition, all of which create the perception in the population at large that public expenditure is slow, ineffective, expensive and often corrupt. Moreover, Agaba and Shipman (2012) posit that the procurement system invariably suffered various forms of malpractice and unethical conduct, including a high incidence of vested interests, interference and insider dealings and occasional cases of retrospective approval of contract awards.

The foregoing background information coupled with the level of public procurement expenditure, provide for a sound justification for determining factors influencing ethical procurement practices in the Tanzanian public entities.

\section{Literature Review}

\subsection{The Principal - Agent Theory}

The theory defines the relationship between the principals, such as shareholders and agents or company executives and managers. In this theory, shareholders who are the owners of the company, hire the agents to perform work. Principals delegate the running of business to the managers, who are the shareholders' agents (Clarke, 2004). In this theory, both an agent and the principal are affected by the action of their relationship such as the agent must choose actions that have consequences for both the principal and the agent (Jensen, 2006).Moreover, the Principal - Agent theory provides the knowledge on procurement decisions to both stakeholders in public procurement process regarding the crucial important of their relationship.

Dependably agency theory assume that in the relationship of this two organs (principals and the agents), agents always are rational self-interested to maximize profits. In regard maximizing utility for principals and the agents is the primary goal. However, it is not assumed that these agents behave selfishly and do so with guile. In other words, slightly contrary to transaction cost economics framework, although it is assumed that people are opportunistic in the sense that they may shirk in a self-interested manner by trying to minimize effort if it fulfils their needs, it is not assumed that they will willingly misrepresent or lie about that effort (Arrow smith, 2003). Indeed inadequate of information sharing between principal and agent can opportunistically take advantage of the situation, sometimes to the detriment of the principal. This latter situation is known as moral hazard and is often the result of asymmetric information which will lead on unethical practices of procurement process (Fama, 2003).

This study considered the principal - agent theory as an effective approach of examining ethical procurement practices in procurement, which is the essence of procurement in public entities. In that respect, the current study perceived the principal - agent theory as the starting point for creating good relationship between the principal and agents through considering ethical issues specifically in procurement process. It allows the development of appropriate tools, 
systems and procedures to appropriately ethical procurement practices in procurement process in the public organization. Moreover this theory is applicable to this study because recognizing the contributions good relationship of National Audit Office and other stakeholders on procurement matters or activities that they perform on behalf of the National Audit Office.

\subsection{Deontological Theory}

The center-piece of Kant's deontological sensibility is the prioritization of duties over consequences. According to Kant, comes from voluntary, informed obedience to the dictates of moral law, regardless of the circumstances (Portmore, 2007). Tethering moral life to the uncertainties of everyday existence is a prescription for socio-political instability, civil chaos and even extreme moral relativism. The violation of a deontological duty is a per se violation of the moral law; consequences are only secondarily relevant (Arneson, 2004). However, of all of the core components in Kant's system freedom constrained by obedience to universal moral law, the prioritization of duties over consequences, recognition of the danger of assuming certainty in the selection of optimal outcomes the categorical imperative, which demands that we not only treat others as ends rather than means, but also treat others as we would want them to treat us, seems to leave room for consequentialist tinkering (Peterson, 2010).

On the one hand, the categorical imperative imposes universal moral duties that will not only stabilize social expectations, but also help to protect individuals from potentially destructive acts committed by others. But the categorical imperative also resembles an agreement between persons on a basic set of guidelines that will ensure individual freedom, civil order and the rule of law, and as such it has a quasi-contractualist sensibility that resembles rule consequentialism.

This theory was potential and seminal to this study as it provides the implicit reasoning behind the rational of ethical practices in procurement process in public organization regarding the agree to abide by rules that require organizations or employees to treat others as ends rather than means, a desirable outcome (universal freedom, morality anchored in law rather than circumstances, stable social expectations) will result.

Moreover this theory was essential to be practiced by public organizations in order to follow legal and generally accepted moral norms of procurement that has been accepted universally and locally such as Tanzania Public Procurement (Amendment) Act of 2016 and Public Procurement (Amendments) Regulations of 2016 (GN 333). As suggested in this theory if employees tend to follow procurement codes of ethics in procurement process, this will and avoid unethical practices on procurement process such as corruption which is improper behaviors.

\subsection{Principles of Public Procurement}

Kotoka, (2010) argue that public procurement principles are the foundation of public procurement and should be addressed in the public procurement rules because they govern the management of public procurement, and also set the framework for a code of conduct for public procurement practitioners and all other officials directly or indirectly associated with the public procurement process. Johnstone and Njenga, (2011) asset that employees must have a clear understanding of public procurement principles, and know how to apply them to guide in public procurement process. Through integrating these principles into their work ethic, the outcome of their decisions will always be in line with the goal of public procurement.

\subsubsection{Value for Money}

This refers to the provision of an institutional function by a private part results in a net benefit to the institution, defined in terms of cost, price, quality, or risk transfer or combination of these (PPA No 21 of 2004). Value for Money (VFM) consider financial and non-financial as the indicator of measuring good performance in public processes.As the fact public procurement is done using public resources, emphasis is put on obtaining value for money. This is because by considering Value for money an organization can obtain to what extent the organization benefit from the goods and services it acquires and / or provides, within the resources available to do it (Byanguye, 2011). Public procurement services should be rendered in an economic and efficient way to give people the best possible value. The communities or taxpayers should be assured that their money is well spent and is used for the correct purposes (PPRA, 2011).

\subsubsection{Transparency}

The word transparency is regarded as the most important term in business governance and in all types of organizations. According to PPA 2011 Regulation 10.-(1) states that a procuring entity shall maintain adequate written records of all procurement, selection or disposal proceedings in which it is involved, and such records shall prescribe tenderers who have responded to advertisements or were approached to tender or to submit expression of interest orproposal, the successful tenderers, the unsuccessful tenderers and the reasons. Regulation 10 (2) states that subject to sub regulation (1), the records shall be made accessible to any authorized person or body, and part of it, as specified in these Regulations, shall be published in the Journal and Tenders Portal.Regulation10 (3) states that without prejudice to sub-regulation (2), information relating to project particulars shall be made available to the general public in a manner and format as shall be prescribed in the guidelines issued by the Authority 
Apparently, lack of transparency in the rules, laws, and public procurement processes creates a favorable environment for corruption. According to Kotoka (2012), transparency or openness means that the same rules should apply to all suppliers of goods, works and services and that these rules are publicized as the basis of the procurement decisions prior to their use. Arrow smith (2003) indicated that transparency can be used as a means to achieve the objectives of preventing corruption, deterring abuse of discretion, maintaining the confidence of contractors in the system and to prevent covert discrimination.

Transparency plays a very critical role in enhancing accountability and inclusiveness and it builds confidence and trust in organizations. Stakeholders can act timorously to remedy challenges and can call on management and the board to account for their actions. Disclosure of information and personal interest by board members provides assurance that the conduct of management supports the principles of good governance.

\subsubsection{Accountability}

A good public procurement system is the main source of financial accountability. Public procurement also serves as a tool of documentary evidence for which organizations can be accounted. Therefore, it is important that the public organizations are transparent to ensure that they are not accountable against any false claim. It has been strongly acclaimed by the World Bank (2011) that the ethical practices in public procurement process are for the purpose of accountability but this accountability is hardly explored. There is a strong connection between ethical practices in public procurement and accountability. Researchers emphasize on the importance of accountability of public procurement system especially in relation to the corrupt officials (Manyara, 2006). Researchers have stated that unethical practices in public procurement process will lead to mistrust and corruption.

Public organizations should always be transparent, accountable and trustable irrespective of its resources. Many studies have indicated in the past the relationship between records management and accountability, which is the pillar of success for any organization free from corruption and other repulsive information hiding behaviors.

\subsubsection{Ethics and Fair dealings}

The impact of ethical practices on the procurement process can equally be massive on the economy of any country. This is because corrupt activities affect economic growth and countries with high corruption rates tend to grow more slowly (Odemba, 2011). This addresses key principles in the Public Procurement Act for equality, fairness and best value for money as spelled out under Section 43 of the PPA, 2011. There is a need to effectively regulate and monitor the ethics and ethical conducts of officials involved in the procurement system to ensure transparency and accountability. According to Kotoka, (2010) ethics are concerned with moral principles and values which govern our belief, actions and decisions. It is the study of moral judgment of right and wrong. Therefore, ethics have to do with upholding moral principles and values which influence our beliefs, actions, and decisions and involves leading an unquestionable lifestyle especially within the professional domain.

\subsubsection{Professionalism}

Professionalism in public procurement allows for functionality, transparency and significant savings in public expenditure and this partly explains why it should be given due attention (URT, 2011). There is a number of indicators that clearly guide the path to professionalism and these include legislative framework, Institutional framework, professional staff transparency and modernization procedures like use of information and communications technology among other adequacies. It is therefore important that all the stakeholders involved in the procurement system fully understands and coordinates work easily (Roodhooft et, al., 2006).

\subsubsection{Integrity}

According to PPRA (2011) integrity takes aspects of the procurement system and governance environment and seeks to ensure that they are defined and structured to contribute to integrity, transparency and has appropriate controls that support the implementation of the system in accordance with legal and regulatory framework and there are appropriate measures in place to address the potential for corruption system. It also covers important aspects of the procurement that include stakeholder as part of control system.

\section{Methodology}

\subsection{Research Design}

In this study, a case study design or strategy was adopted. According to Yin (2009), a case study is an empirical inquiry that investigates a contemporary phenomenon in depth and within its real-life context, especially when the boundaries between the phenomenon and the context are not clearly evident .Therefore, a case study was used because the researcher wanted to get an understanding of the real phenomenon under investigation, and that such understanding would encompass important contextual conditions because they are highly pertinent to the phenomenon of study which is understanding procurement ethical practices in the public procurement processes. In additional a case study was relevant 
since the data for the study were collected through a single case study namely National Audit Office -Headquarters in Dar Es Salaam.

\subsection{Population of the study}

Since the study adopted a case study design, then the target population was all employees currently working with the National Audit, at the Headquarters Office located in the city of Dar Es salaam. This involved all personnel from the procurement management unit, accounting, transport, engineering, legal, administration and internal audit departments/sections. According to National Audit Annual Reports of 2016 and at the time when this study was conducted, there were a total of fifty (50) employees at the Headquarters' Office.

\subsection{Sampling Techniques}

This study used stratified sampling and purposive sampling techniques to obtain the suitable respondents to engage in the study. Sampling techniques provides a range of methods that enabled the researcher to deduce the amount data to be collected, basing on the selected representative of the population rather than the whole (Creswell, 2009).

Stratified randomly sampling was used to select twenty three (23) respondents from different sections or departments to whom questionnaire were issued or distributed. Then the researcher used simple random probability to draw a sample from each section or department\| depending on the availability of respondents in each section. The approach was appropriate for this study as it ensures the fair representation from every department or section but also it ensure the grouping or separating participants into non-overlapping groups.

Purposive sampling was used to select seven (7) heads of departments or sections as the key informants in this study. These were heads of the seven departments / units of the NAO Headquarters namely, Procurement, Accounting, Transport, Engineering, Legal, Administration and Internal Audit.

\subsection{Sample size}

From a total population of 50employees, a sample size of 30 which is equivalent to $60 \%$ of employees was taken. The researcher considered the chosen sample size as suitable because it fulfilled the requirements of efficiency, representative, reliability, flexibility and precision of the study as propounded by Cooper and Schindler (2008);Mugenda and Mugenda (2006) and Creswell (2009). The following table indicates the sample size determination for this study.

\begin{tabular}{|c|c|c|c|}
\hline Departments & Population & Sample Size & Percentage \\
\hline Procurement Management Unit & 9 & 5 & 55 \\
\hline Accounting & 24 & 15 & 62 \\
\hline Transport & 2 & 1 & 50 \\
\hline Engineering & 2 & 1 & 50 \\
\hline Legal & 4 & 2 & 50 \\
\hline Administration & 6 & 4 & 67 \\
\hline Internal Auditors & 3 & 2 & 67 \\
\hline Total & 50 & 30 & 60 \\
\hline
\end{tabular}

Table 1: Sample Size Determination

\subsection{Data Analysis}

Before analysis, the collected data were edited, coded, classified, and tabulated so that they are amenable for analysis. Using the Statistical Package for Social Science (SPSS) version 20, the collected data were analyzed. The quantitative data were analyzed using descriptive analysis. Such descriptive analysis provided simple summaries of the characteristics of the sample such as measures of central tendency, frequencies and percentages, among others. Qualitative data were analyzed though thematic and content analysis techniques. Both techniques were employed to facilitate the easy coding and classifying data, also referred to as categorizing and indexing.

\section{Research Findings}

The main findings of this study are summarized and presented based on the specific objectives as depicted in the following tables.

\begin{tabular}{|c|cc|cc|}
\hline Constructs (Sub-Variables) & \multicolumn{2}{|c|}{ Agree } & \multicolumn{2}{c|}{ Disagree } \\
\hline Equality in treatment & 29 & $(97 \%)$ & 1 & $(3 \%)$ \\
\hline Bidders have the right to challenge procurement decisions & 20 & $(67 \%)$ & 10 & $(33 \%)$ \\
\hline Openness in the procurement processes and decisions & 27 & $(90 \%)$ & 3 & $(10)$ \\
\hline Impartiality of officials involved in the procurement process & 25 & $(83 \%)$ & 5 & $(17 \%)$ \\
\hline
\end{tabular}

Table 2: Effect of Fairness on Procurement Ethical Practices 


\begin{tabular}{|c|cc|cc|}
\hline Constructs (sub-variables) & \multicolumn{2}{|c|}{ Agree } & \multicolumn{2}{c|}{ Disagree } \\
\hline Access to procurement information & 24 & $(80 \%)$ & 6 & $(20 \%)$ \\
\hline Existence of procurement audits (internal and external) & 28 & $(93 \%)$ & 2 & $(7 \%)$ \\
\hline Bidders are treated with the same rules & 27 & $(90 \%)$ & 3 & $(10)$ \\
\hline Unsuccessful bidders are notified of the decisions made & 26 & $(87 \%)$ & 4 & $(13 \%)$ \\
\hline
\end{tabular}

Table 3: Effect of Transparency on procurement ethical practices

\begin{tabular}{|c|cc|cc|}
\hline Constructs (Sub-Variables) & \multicolumn{2}{|c|}{ Agree } & \multicolumn{2}{c|}{ Disagree } \\
\hline Compliance with procurement rules and regulations & 28 & $(93 \%)$ & 2 & $(7 \%)$ \\
\hline Resources are used for the intended purpose & 26 & $(87 \%)$ & 4 & $(13 \%)$ \\
\hline Adherence to procurement professionalism & 28 & $(93 \%)$ & 2 & $(7)$ \\
\hline $\begin{array}{c}\text { Stakeholders' opportunity to question the procurement process and } \\
\text { decisions }\end{array}$ & 21 & $(70 \%)$ & 9 & $(30 \%)$ \\
\hline
\end{tabular}

Table 4: Effect of Integrity on Procurement Ethical Practices

\begin{tabular}{|c|cc|cc|}
\hline Constructs (sub-variables) & \multicolumn{2}{|c|}{ Agree } & \multicolumn{2}{c|}{ Disagree } \\
\hline Existence of Code of Ethics & 30 & $(100 \%)$ & 0 & $(0 \%)$ \\
\hline Clear job description & 30 & $(100 \%)$ & 0 & $(0 \%)$ \\
\hline $\begin{array}{c}\text { Adherence to the existing Code of ethics and conduct } \\
\text { Code of ethics and conduct is applicable to all employees at the } \\
\text { entity }\end{array}$ & 28 & $(93 \%)$ & 2 & $(7)$ \\
\hline \begin{tabular}{c}
$(87 \%)$ \\
\hline
\end{tabular} & 4 & & $(13 \%)$ \\
\hline
\end{tabular}

Table 5: Effect of Code of Ethics and Conduct on Procurement Ethical Practices

\section{Conclusion}

The findings of this research indicate that NAO (HQs) procurement activities are conducted in fair and transparent manners which are the main ingredients of ethical practices. Furthermore, from the results of this study, it can be concluded that NAO (HQs) observes the code of ethics and conduct on procurement process which enhance ethical practices in procurement process. From the findings of this study, it is also fair to argue that procurement should be seen as a profession that must be conducted by professional staff. That is to say employment of professional procurement staff and clearly defining roles and giving job descriptions will minimise the incidence of conflict of interest, improve supervision and enhance ethical behaviour.

Generally, the study concludes that all of the four (4) independent variables namely fairness, transparency, integrity and code of ethics have effect on ethical procurement practices at NAO (HQs), and hence this answers our research questions and achieves our research objectives. The four identified independent variable $s$ are indeed the disinfectants of corruption and fraudulent in the public procurement system in Tanzania.

\section{Recommendations}

The study recommends that ethical procurement practices and audit performance of professionals should consistently be evaluated so as to ensure procurement activities are conducted in compliance with the laws.There is also a need to develop a code of conduct manual for procurement officials who must be made to sign an undertaking to adhere to the code. This will not only help restore the damaged perceptions of the public on the tender agencies, but also make the tender process a viable economic activity that will contribute to the socio-economic development of the country instead of being seen as an activity through which public assets are converted into private wealth.

On the issue of training, the organization should provide training to employees to enhance their effectiveness and efficiency in their work. Information or documents on ethical procurement practices should be made available to all the procurement officials as well as all officials who are directly involved in procurement activities to ensure compliance with ethical practices of the organization. Furthermore, improvement in ethical procurement practices should be seen as a responsibility of each and every employee in an organization.

\section{References}

i. Achuora, J., Arasa, R. \& Ochriri, G. (2011). Precursors to effectiveness of public procurement audits Constituency Development Funds (CDF) in Kenya. European Scientific Journal, 8(25), 198-214.

ii. Agaba, E., \& Shipman, N. (2012). Public procurement reform in developing countries: The Uganda Experience. Accesses from http:// www ippa.ws/ IPPC2/ Book.

iii. Arneson, R. 2004 'Opportunity for Welfare, Priority and Public Policy', ed. by Steven Cullen erg and Prasanta K Pattanaik, Globalization, Culture and the Limits of the Market: Essays in Economics and Philosophy (New Delhi: Oxford U. Press, 2004). 
iv. Arrowsmith, P. (1998). Purchasing practice in Dutch municipalities. International journal of purchasing and material management, 31-36.

v. Arrowsmith, P. (2003). Purchasing practice in Dutch municipalities. International journal of

vi. Ayoyi, I.S. and Mukoswa, O. (2015). Ethical Issues in Public Procurement in Kenya. International Journal of Scientific and Research Publications, 5(9).

vii. Banihashemi, F. (2011). "Sustainable Procurement in Practice: Lessons from Local Government", Journal of Environmental Planning \& Management, Vol. 50 No.3.

viii. Byanguye, J. (2011). Anticorruption in Public Procurement in Nigeria: Challenges and Competency Strategies. Journal of Public Procurement, 11 (3), 323-353.

ix. Byanguye, M. (2011). The effectiveness of internal control systems in achieving value for money in school facilities grant. The case of Kamuli district local government.

x. Chigudu, D. 2014. Public procurement in Zimbabwe: issues and challenges. Journal of Governance and Regulation, 3(4):21-26.

xi. Cooper, D.R., \& Schindler, P.S. (2008). Business Research Methods. (8th Ed.). Boston: 15 McGraw-Hill Irwin.

xii. Cooper, D.R. \& Schindler, P.S. (2008). Applied multiple regression/ correlation analysis for behavioral Sciences, New York: Wiley.

xiii. Creswell, J. W. (2009). Research design: qualitative, quantitative and mixed methods approaches. 3rd Ed. Los Angeles: Sage Publications.

xiv. Creswell, J.W. (2012). Educational Research: Planning, Conducting, and Evaluating Quantitative and Qualitative Research. Upper Saddle River, NJ: Prentice Hall.

xv. Durant, R.F. and Durant, J.R.S. (2013). Debating public administration: management challenges, choices and opportunities. Boca Raton: CRC Press.

xvi. Fama, F. (2003). Separation of Ownership and Control. Journal of law and Economics.

xvii. Hui, W. S., Othman, R. O., Normah, O., Rahman, R. A. \& Haron, N. H. (2011). Procurement issues in Malaysia. International Journal of Public Sector Management, 24(6), 567- 593.

xviii. Jackson, N\& Eunice, (2014). The role of ethics in procurement process effectiveness in the water sector in Kenya: A Case Study of EWASCO, Embu County. International Journal of Supply Chain Management, Vol. 3, No. 3.

xix. Jensen, M. C. (2006). Theory of the Firm. New York: York work press.

xx. Jensen's, P., D., \& Mackling's, R. (2006). Strategic Supply and the Management of Inter-and intra-Organizational Relationships. Journal of Purchasing and Supply Management, 9(1).

xxi. John, K. N. and Mugo, H. (2010). "Internal Factors Affecting Procurement Process of Supplies in the Public Sector; a survey of Kenya government ministries". Retrieved from http:/ / www.ippa.org/ IPPC5/ Proceedings/ Part8/ PAPER8-9.pdf.

xxii. Johnstone, K. N. (2011). Client-Acceptance Decisions: Simultaneous Effects of Client.

xxiii. Kakwezi, P. and Nyeko, S. (2008). Procurement Processes and Performance: Efficiency and Effectiveness of the Procurement Function. http./ www.cips.org/ documents/ performance measurement.pdf. (7thNovember, 2012).

xxiv. Kizito, E.K, \& Khomba,J.K. (2013). The impact of procurement operations on healthcare delivery: A case study of Malawi's public healthcare delivery system. Global Journal of Management and Business Research Administration and Management, 13(3), 26-35.

xxv. Kothari, C. R. (2013). Research methodology: methods and techniques. New Delhi: Wishwa Prakashan.

xxvi. Kotoka, A, F. (2012) "Assessing the Level of Compliance with the Public Procurement Act, 2003 (Act 663) in Public Entities in Ashanti Region of Ghana". Kwame Nkrumah University of Science and Technology. Ghana. dspace.knust.edu.gh:8080jspui/ bitstrea.

xxvii. Manyara, (2006.) Assessment of Annual Procurement Planning.

xxviii. Mlinga, R (2008). Re-emphasizing the Need for Procurement Planning in Tanzania. Procurement Journal vol.1 no.17.

xxix. Mugenda, O. M. (2006). Research Methods. Qualitative and quantitative methods. Nairobi: ACTS.

xxx. Mugenda, O. M. \&Mugenda, A. G. (2003). Research Methodology; Qualitative and Quantitative: African Centre for Technology Studies (ACTS) Press.

xxxi. Ngugi, J. K. and Mugo, H.W. 2012. Internal factors affecting procurement process of supplies in the public sector: A survey of Kenya government ministries. Journal 5th International Public Procurement Conference was held on August 17th.

xxxii. Odemba, A.S. (2011). Corruption in Sub-Sahara Africa A phenomenological study. University of Phoenix. Proquest. UMI. Online library.wiley.com. Vol 3.

xxxiii. Odhiambo, W. (2012), Public Procurement: Lessons from Kenya, Tanzania and Uganda, OECDDevelopment Centre Working Paper No. 208.

xxxiv. Odhiambo, W., and Kamau, P. (2003), Public Procurement: Lessons from Kenya, Tanzania and Uganda, OECD Development Centre Working Paper No. 208. 
xxxv. Peterson M. 2010 'Can Consequentiality Honour the Special Moral Status of Persons?' Utilities 22 (2010) 4.

xxxvi. Portmore, R. (2007). Obstacles to public procurement reform in developing countries. The Netherlands: Kluwer International.

xxxvii. Quinot, G. and Arrowsmith, S. (2013). Public procurement regulation in Africa. New York: Cambridge University Express.

xxxviii. Roodhooft, F. \& Abbeele, A. V. D. (2006). Public procurement of consulting services Evidence and comparison with private companies. International Journal of Public Sector Management, 19(5).

xxxix. Rossi, D.N. (2010)."Measuring losses to public procurement corruption: The Uganda Case”, 3rd International Public Procurement Conference Proceedings.

xl. Thai, K.V. (2001). "Public procurement re-examined", Journal of Public Procurement, Vol. 1 No.1, pp.9-50.

xli. World Bank. (2011). Procurement under IBRD Loans and IDA Credits, World Bank. WashingtonD.C: World Bank.

xlii. Yin, R.K., (2009). Case Study Research: Design and Methods. Beverly Hills, Calif: Sage Publications.

xliii. Zitha H.E and Mathebula N.E. 2015. Ethical conduct of procurement officials and implication on service delivery: a case study of Limpopo provincial treasury. Unethical conduct of procurement officials may also result in service delivery protests and loss of life. Public and Municipal Finance, $4(3): 16-24$.

xliv. Zhou G (2012) Three Decades of Public Enterprise Restructuring in Zimbabwe a will-Of-The-Wisp Chase?. Harare International Journal of Humanities and Social Science 